\title{
The Political Economy of the Egyptian and Arab Revolt
}

\author{
Omar S. Dahi*
}

Abstract This article advances a framework for understanding the political economy of the Egyptian and
Arab revolts. After almost three decades of implementing neoliberal economic policies, the Egyptian
economy was nevertheless stagnating in the early 2000 s and political unrest was increasing. In response two
key policy decisions were undertaken by the ruling elite, one to embark on a programme of further
liberalisation and privatisation in the hope of attracting foreign direct investment and the other to use the
global war on terror framework as a means of repressing internal dissent. While these decisions 'succeeded'
in the short term, they also created the conditions which led to the uprisings.

\section{Introduction}

On the critical end, the annual Arab Human Development Reports, launched in 2002 by the UN Development Programme, have painted a picture of stagnation, rapidly increasing poverty and inequality, as well as gender gap and other disparities. Alternatively, several countries in the Arab Middle East and North Africa were also described as success stories by multinational institutions, including the International Monetary Fund (IMF) who repeatedly praised Tunisia and Egypt's economic performance. ' Even after the uprisings, a columnist in the New York Times argued that economic success was behind the revolution in Egypt, since it unleashed the forces of an 'entrepreneurial middle class' ${ }^{\text {' }}$ and made Egypt 'the eighteenth easiest nation in which to start a business' (Ayres and Macey 2011). The reality is that there is some truth to both narratives, but that neither fully captures the course of economic development in Arab countries over the last 25 years. The explanation for the uprisings is better found in the political economy of regime consolidation than in aggregate statistics, whether one glosses them favourably or unfavourably. In addition, key policy decisions taken in the early 2000s hastened the demise of the Egyptian (and Tunisian) regimes and perhaps others to follow.

By the late 1990s and early 2000s, several countries in the Arab Middle East and North
Africa, including Egypt, had reached a difficult impasse. On the one hand, their economies were stagnating, and gross domestic product (GDP) growth rates were in decline (Figure 1). They had launched major programmes of economic liberalisation in the late 1970s, 1980s or early 1990s, depending on the country. Despite the results, the governments were under pressure from emerging forces inside the regimes (as well as from outside) to expand the programmes. As late as 2004, the IMF was urging 'significant acceleration of the pace of structural adjustment' in Egypt. ${ }^{3}$ On the other hand, this process had undermined the autocratic model of power consolidation that the regimes had spent years refining, or perhaps in their minds, perfecting.

Egypt and some of the other regimes' response was twofold: first, it embarked upon further liberalisation with the primary goal of attracting foreign direct investment from Europe, North America and China, including the signing of bilateral free-trade agreements with the EU and USA and a massive programme of privatisation. Second, after the al-Qaeda attacks of 9/11, it adopted the Bush administration's framework of a 'global war on terror', enabling them to dedicate more resources to repression of escalating dissent. These two choices, however, further weakened the grip of the regime; the first causing splits in the business elite and the second alienating the educated middle-classes,

IDS Bulletin Volume 43 Number 1 January 2012 (c) 2012 The Author. IDS Bulletin @ 2012 Institute of Development Studies Published by Blackwell Publishing Ltd, 9600 Garsington Road, Oxford OX4 2DQ, UK and 350 Main Street, Malden, MA 02148, USA 
Figure 1 Egypt annual GDP growth rates, 1990-2009

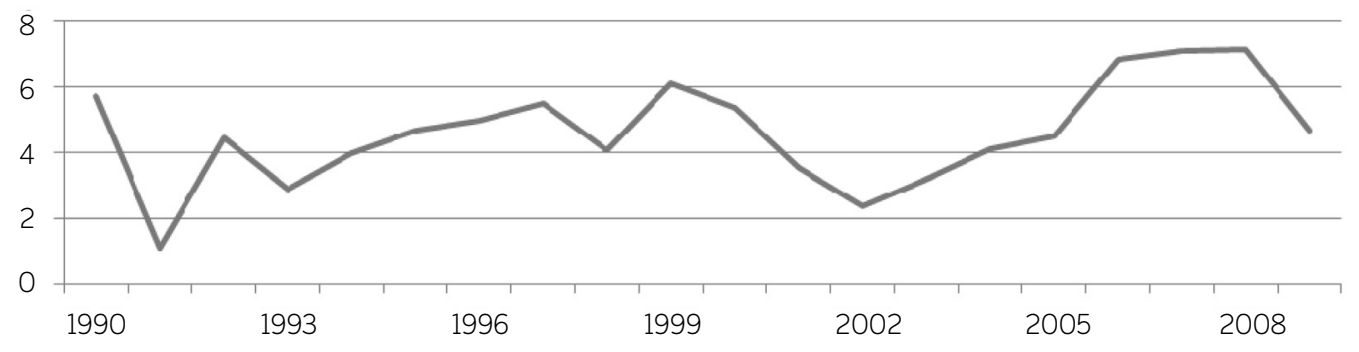

Source World Development Indicators online database (data.worldbank.org).

with increasingly arbitrary state behaviour, lack of rule of law and rising corruption. The regimes were able to hang on for another decade, but it was clear that they were living on borrowed time. The ruling cliques of Zine El Abidine Ben Ali and Husni Mubarak were finished off by the worldwide financial crisis beginning in 2008, which led to declines in foreign direct investment and a slowdown of economic growth (Brach and Loewe 2010), when there were few if any social forces to come to their defence (see below).

\section{The rise and fall of the social contract}

After independence in 1952, Egypt was a model for the populous Arab countries in combining authoritarian rule with a redistributive welfare state served by a large bureaucracy. The state owned industrial and other enterprises employing an urban workforce that provided agricultural support to the peasantry and supplied extensive subsidies for basic consumer goods. This corporatist model - called 'authoritarian populist' by political scientists - consolidated power by trading development for the political loyalty of key social forces, such as workers, peasants, professionals and others in the educated middleclass. Not all citizens accepted the tradeoff, of course; many resisted and paid a hefty price. Particularly in the early post-independence years, however, the Arab regimes built their legitimacy on aspirations for a developmental state.

The development outcomes in the Arab world were substantial. The economists James E. Rauch and Scott Kostyshak divide the region into three categories: the Arab Mediterranean (Egypt, Jordan, Lebanon, Morocco, Syria and Tunisia); Arab sub-Saharan Africa, including Yemen; and 'fuel-endowed countries', encompassing Iraq and the Gulf monarchies, as well as Algeria and Libya (Rauch and Kostyshak 2009).
The focus in this article is on Egypt, classified as part of the Arab Mediterranean. All the Arab Mediterranean countries are middle-income countries with similar economic structures and economic trajectories to other post-colonial middle-income countries (e.g. large peasant sector alongside urbanisation and a manufacturing-industrial sector; policy sequencing of first substantial state-led development followed by liberalisation). However, Egypt had not gone through the wave of democratisation. Also, unlike the pure 'rentier-states' in the region, they have relatively little oil and natural gas endowments and are thus more constrained in terms of expenditures. These two characteristics separate them from the remainder of the Arab Middle East and North Africa, including countries like Algeria - which otherwise had a very similar trajectory - with a large carbon endowment, and Yemen which has remained a low-income economy with little to no diversification of production structures. Taking issue with the Arab Human Development Report's dismal prognosis, Rauch and Kostyshak argue that most of these countries inherited abysmal conditions from colonial times and have nevertheless made dramatic progress.

Many Arab countries have increased both life expectancy and rates of education by a greater percentage than other developing regions, or even the world, since 1970. For example, life expectancy in the Arab Mediterranean countries was 52 years in 1970 and 71.4 in 2007, an increase of 19.4, while the comparable numbers in Latin America were 60.4 and 73.1, an increase of only 12.7 years. From 1970 to 2007, the average number of years of education went up from 1.4 to 5.5 in the Arab Mediterranean, an increase of 4.1 years, whereas for Latin America, 
Figure 2 Egypt foreign direct investment, net inflows (\% of GDP), 1990-2009

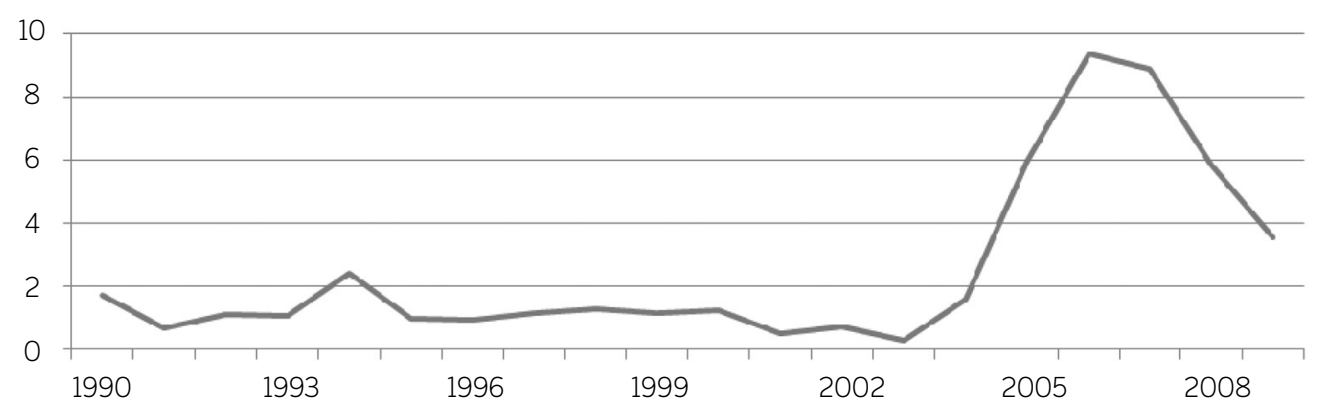

Source World Development Indicators online database (data.worldbank.org).

the number rose from 3.4 to 5.7 , an increase of 2.3 years. In fact, the Arab Mediterranean outperformed southern Europe and the rest of the non-Arab world in both of those categories over the same time period.

None of these regimes, however, were able to build a truly developmentalist state.

Developmentalist states are able to use public investment and state expenditure to create an economy characterised by 'a set of assets based on knowledge, exploited by skilled labor'

(Amsden 2001) with 'highly selective meritocratic recruitment' (Evans 1995). Key to these efforts are the establishment of a nonpoliticised bureaucracy that is able to enforce accountability and quality control on the private or mixed sector and technological upgrading that allows industry to compete on international markets. The post-independent Arab countries were able to seize the commanding heights of the economy. They raised protectionist tariffs, expanded infrastructure and undertook huge investments in human as well as physical capital development, with success in simple manufactures as well as more sophisticated and heavy industry. In almost all cases however, the development bureaucracy served primarily political goals and therefore could not enforce performance outcomes like its more technocratic counterparts in the Asian tigers.

Starting in the mid-1970s in Egypt, the authoritarian populist social contract began to unravel; along with it, the impressive developmental accomplishments began to stall and, in some cases, retreat. GDP growth rates that averaged around 6 per cent per year in the 1960s became less than 1 per cent in the 1980s. Total factor productivity, which measures contributions of human and physical capital, which was a robust 3.4 per cent in the $1960 \mathrm{~s}$, became -1.5 per cent in the $1980 \mathrm{~s}$ and stagnated throughout the 1990s (Yousef 2004). While the Arab Middle East had one of the lowest incidences of poverty and income inequality during the 1960s-early 1980s period, the Arab Human Development Report (UNDP and AFESD 2002) projected that about 40 per cent of Arabs, approximately 65 million people, live in poverty. New social forces, particularly the emerging merchant-manufacturing class, increasingly pushed for using the state as an instrument of wealth accumulation rather than for redistributive or productive investment purposes. In many cases, these merchant-manufacturers had enriched themselves through mere business or kinship ties to the ruling apparatus. They exploited this proximity to become even richer in the era of structural adjustment. When some of the regimes ran into macroeconomic problems such as severe current account deficits or financial crises, the IMF, World Bank and other institutions reinforced the neoliberal message.

\section{Fateful decisions}

By the late 1990s, much of the region had gone through two decades of structural adjustment characterised by the trinity of economic liberalisation, deregulation and privatisation. The economies of most countries, however, were not growing as rapidly as hoped.

Figure 1 shows the yearly rates of GDP growth per capita in Egypt from 1990 to 2009. The data shows on average, a growth rate through the early 1990s, then a decline by the first few years of the new millennium, followed by a rise in the mid-2000s until the worldwide financial crisis hit with full impact in 2008. The rise of GDP growth 


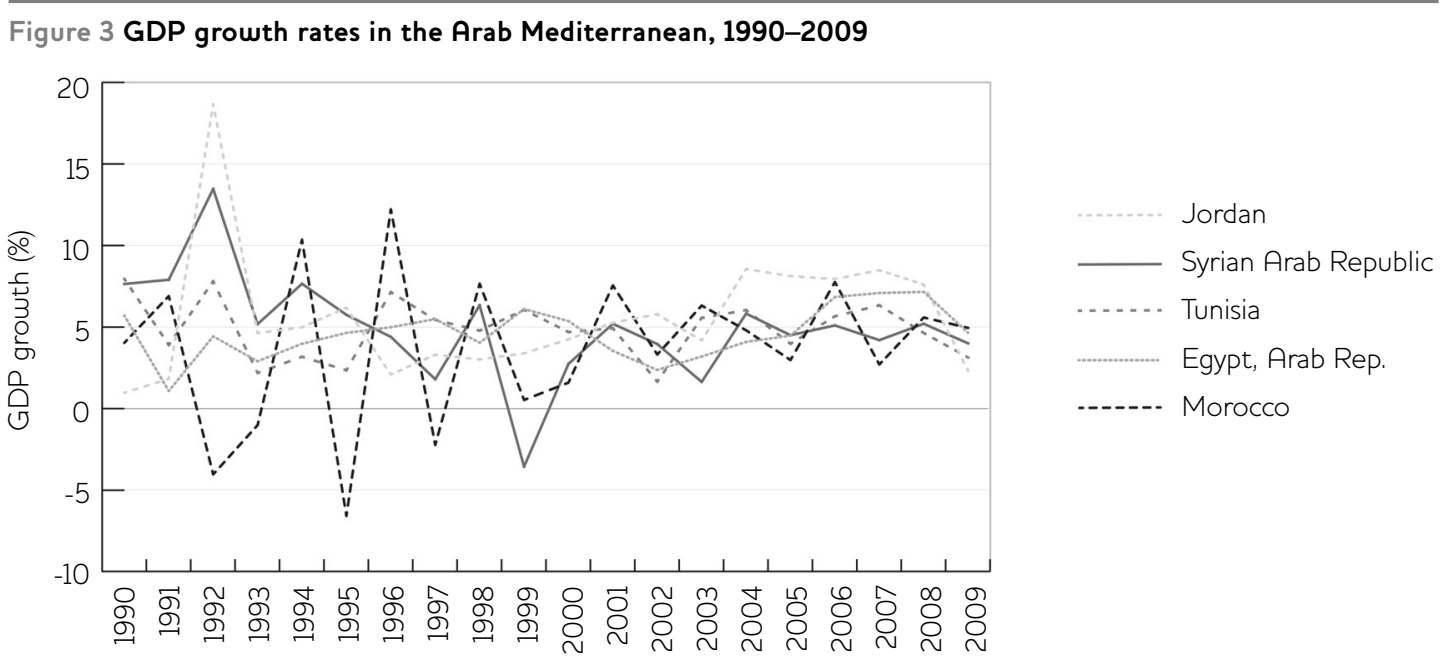

Source World Development Indicators online database (data.worldbank.org).

rates in the mid-2000s, however, hides the mechanism through which they were achieved: a policy decision to open the floodgates to private capital, foreign and domestic, and therefore make growth dependent on flows of foreign and domestic investment.

Figure 2 illustrates this finding more clearly. As a percentage of GDP, net inflows of foreign direct investment increased dramatically in Egypt.

Figures 3 and 4 repeat the same exercise for the rest of the Arab Mediterranean (excluding Lebanon) to show that there were similar processes taking place. Both graphs show an upward trend, but in the 2000s there is an obvious quantitative increase - in some cases quite dramatic - across the Arab Mediterranean. GDP growth rates and inflows of investment dollars jumped at the beginning of 2004, after the 'reform government' of Ahmad Nazif took power in Egypt. In particular, the pace of privatisation of state-owned enterprises picked up, after a slowdown around the turn of the millennium (Figure 5), as more companies were sold off in full or in part. Markets were ecstatic at this turn of events. 'If privatisation was the test, then [the Nazif] government has proved its mettle', gushed one investor newsletter. 'Investor confidence in the country has skyrocketed. The future looks bright for Egypt' (Emerging Markets Monitor 2005). The Hermes stock index raced upward.

Figure 4 Arab Mediterranean foreign direct investment, net inflows (\% of GDP), 1990-2009

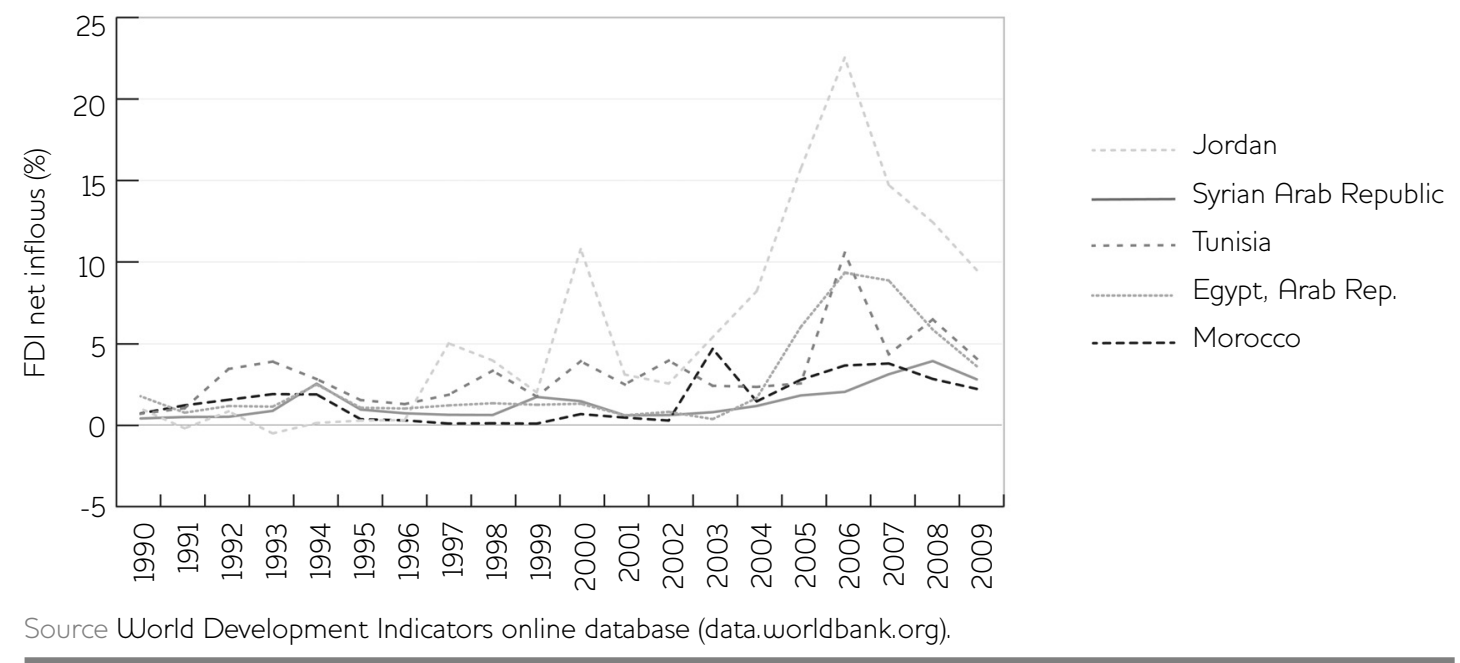


The Nazif government solved one problem while creating others, however. Arguably, it caused irreversible damage to the remaining political base of the regime. While the newer capitalists close to the regimes were beneficiaries, the dramatic opening angered many of the business elite who still had vested interests in a semblance of a national market. Signs of these conflicts can be traced through anxiety in the business press. As early as September of 2007, the Emerging Markets Monitor had identified growing worker strikes and sit-ins as a threat to the campaign of privatisation. More importantly, it identified the campaign, 'No To Selling Egypt', launched by a former state-owned enterprise manager, as gaining traction in the Egyptian parliament. This campaign was not merely by 'leftist opposition', as the Monitor's release stated.

And the opposition is not just coming from the public. The No To Selling Egypt campaign run by Yehia Hussein Abdel Hady is gaining traction within parliament, with the support of the handful of leftist opposition ministers of parliament as well as the Muslim Brotherhood. Interestingly, the official policy of this latter group, the most popular opposition force, is not necessarily informed by the populist view: 'We are for privatisation provided that the assets of the companies to be sold receive a fair valuation', said the group's economic adviser, Abdel-Hamid al-Ghazali. However, in practice it seems that its members are supporting Abdel Hady's campaign, which is based around the argument that the government has undersold Egyptian assets.

(Emerging Markets Monitor 2007)

By 2010, the divisions over the economic programme had spread into the upper echelons of the policy elite. The Monitor's January 2011 political and economic outlook report identified this split as tied to Gamal Mubarak's succession, but that it was signified through opposition to economic reforms. Although they reassured investors that 'a massive uprising in popular discontent remains outside our core scenario', they nevertheless added that:

More important to watch will be any shift in relative power dynamics among the 'old' and 'new' guard factions within the NDP [National Democratic Party], particularly as this might provide an indication into the future presidential succession question. As recent reports have indicated that the older entrenched elites (represented by individuals such as Secretary General Safwat al-Sharif and Presidential Chief of Staff Zakaria Azmi) have been able to exert greater influence on internal party dynamics of late, any increase in their support base could signal their further consolidation of power. Given this group's broad opposition to President Mubarak's son, Gamal, taking over power after his father, we would take any power shift in their direction as the end of the younger Mubarak's presidential bid. For foreign investors, we

Figure 5 Egypt state-owned enterprises totally or partially privatised, 1993-2006

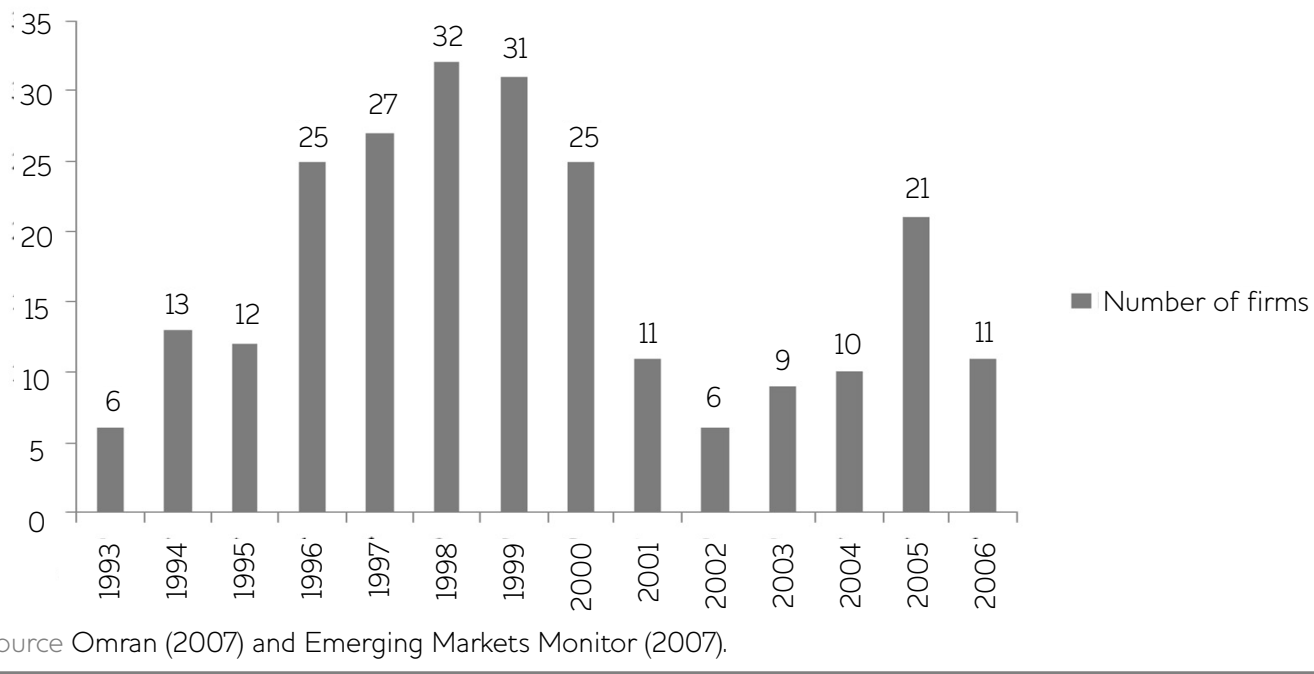


stress that given this faction's resistance to the series of economic reforms that have been pushed through since 2004, we would take any further consolidation of power in their direction over the next few months as an indication that little should be expected out of the government in terms of further economic reforms, at least in the near term.

(Emerging Markets Monitor 2011)

Meanwhile, structural adjustment in the 1980s and 1990s had seen Egypt largely abandon its legacy of support for workers and peasants. The very language of 'peasants and workers', once a prominent prop of the authoritarian populist model of rule, disappeared from the lexicon of regimes, unable or unwilling to abide by the social contract. Alongside the shifts in policy and rhetoric, uprisings based on economic (and political) grievances erupted across the region: Egypt in 1977; Morocco in 1981 and 1984; Tunisia in 1985; Algeria in 1988 and Jordan in 1989. The increase in global food prices since 2007 contributed to another wave of such 'bread riots' in several countries, including Mauritania and Morocco, lasting up to the outbreak of the Tunisian revolution. In Egypt, some 1.7 million workers took part in over 1,900 strikes between 2004 and 2008, before the financial crisis, when the number of strikes and work stoppages reached into the thousands (Solidarity Center 2009). The labouring classes were reacting in fury, not only to their higher cost of living, but also to the mounting extravagance and conspicuous consumption of the elite (see Ali, this IDS Bulletin).

\section{Pyrrhic victories}

The second fateful decision came shortly after 9/11, when Washington's newly aggressive neoconservative orientation presented both a threat and an opportunity. Having launched one war in Afghanistan and telegraphed another in Iraq, the Bush administration constrained the ability of regional allies to pursue independent foreign policies. On the other hand, the Arab regimes quickly learned that by casting their internal enemies as those of the USA as well, they could attract more resources to dedicate to repression. Many of the regimes projected the image of 'liberalised autocracy' by making and reversing concessions depending on the degree of internal and external pressure. Pleasing the West took the additional form of what can only be described as public relations campaigns, as regimes (and first ladies) spoke the language of civil society, anti-extremism and modernisation; all winks at the liberal sensibility.

Coupled with the heightened belligerence of the security services, the policy decisions of the political elite were clearly losing friends for the regimes. Even segments of the professional and managerial class that hitherto had been explicitly non-political began to chafe at the outlandish behaviour of the secret police in particular (see Tadros, this IDS Bulletin). The politically minded among the educated middle-classes were struck with an iron fist (see Ali, El Naggar, Ezbawy, Abd el Wahab, this IDS Bulletin). By the late 2000s, the Arab states had become virtual oligarchies with an isolated and hated ruling elite.

Understanding the political economy of regime consolidation helps one to understand the Arab revolts better than a simple focus on deprivation or economic success. In a way, the regimes succeeded in solving their immediate problems. They were accepted by the West as partners, and cast their domestic cruelty as an honourable fight against terrorism. They managed to bolster the rates of economic growth, in some cases quite significantly. But these victories proved to be pyrrhic, as the regimes also succeeded in alienating whatever social base they had left. Perhaps it would have been possible for the regimes to make other decisions, for instance, to engage in meaningful political reform and relax emergency law. They could have re-thought the model of economic development and attempted to rewrite an inclusive social contract with workers and peasants. They did not, and perhaps could not, do so. It is clear, however, that the reforms they tried to initiate after the uprisings broke out, came almost a decade too late.

The Egyptian and Arab revolts have occurred within a global context that is witnessing a general crisis of capitalism. Although the persistence of authoritarianism had been unique to the Arab world, the economic policies they employed were not. The USA has suffered the results of financialisation and structural adjustment policies have now reached the First World, with countries like Greece and Italy being subjected to harsh conditionalities and IMF monitoring. Needless to say, this current period is an opportunity to think and implement different approaches to economic development away from 
unfettered free markets, trade and financial flows. However, the experience of the Arab Middle Eastern economies provides global lessons for development that should be kept in mind when alternative approaches to development are discussed. First, the experience of the successful developmentalist countries shows that there should be an expanded role for the state in the economy, including active industrial policy (Chang and Grabel 2004; Amsden 2001). However, the trajectory of the Arab states indicates that the lack of democracy in the Arab world did hurt economic development. The

\section{Notes}

* This article is adapted from a version that first appeared in the Middle East Report 259, Summer 2011.

1 Source: www.english.globalarabnetwork.com/ 201009017095/Economics/imf-praisestunisias-economic-policies-and-reforms.html

\section{References}

Amsden, A. (2001) The Rise of 'The Rest': Challenges to the West from Late-Industrialising Economies, Oxford: Oxford University Press

Ayres, I. and Macey, J. (2011) 'Did Egypt's Rising Economy Lead to Hosni Mubarak's Fall?', Politico, 18 February

Brach, J. and Loewe, M. (2010) 'The Global Financial Crisis and the Arab World: Impact, Reactions, and Consequences', Mediterranean Politics 15.1: 45-71

Chang, H.J. and Grabel, I. (2004) Reclaiming Development: An Alternative Economic Policy Manual, London: Zed Books

Emerging Markets Monitor (2011) 'Egypt Business Forecast Report', Chapter 2 Economic Outlook, Business Monitor International, 1 January

Emerging Markets Monitor (2007) 'Egypt: Privatisation Process on Track... Just', Business Monitor International, 3 September

Emerging Markets Monitor (2005), 30 May

Evans, P. (1995) Embedded Autonomy: States and Industrial Transformation, Princeton NJ: Princeton University Press: 12 authoritarian regimes inhibited the establishment of horizontal (governmental checks and balances; independent judiciary) and vertical (media and popular pressure from below) accountability mechanisms (Mainwaring and Welna 2003), which would strengthen domestic institutions. This is now seen as the main indicator for successful economic growth (Rodrik 2007). Therefore, the path towards achieving effective human development in the Arab world and beyond must take into account strengthening democratic institutions as well as addressing social justice and economic growth.

2 Source: www.freakonomicsmedia.com/2011/ 02/22/memo-to-syria

3 Source: www.imf.org/external/np/sec/pr/2004/ pr04227.htm

Mainwaring, S. and Welna, C. (2003) Democratic Accountability in Latin America, Oxford: Oxford University Press

Omran, Mohammed (2007) 'Privatization, State Ownership, and Bank Performance in Egypt', World Development 35.4: 714-33

Rauch, James E. and Kostyshak, Scott (2009) 'The Three Arab Worlds', Journal of Economic Perspectives 23.3: 165-88

Rodrik, D. (2007) One Economics Many Recipes: Globalization, Institutions, and Economic Growth, Princeton: Princeton University Press

Solidarity Center (2009) The Struggle for Worker Rights in Egypt, Washington DC: 14

UNDP and AFESD (Arab Fund for Economic and Social Development) (2002) Arab Human Development Report 2002: Creating Opportunities for Future Generations, New York: United Nations Development Programme

Yousef, T. (2004) 'Development, Growth and Policy Reform in the Middle East and North Africa Since 1950', Journal of Economic Perspectives 18.3: 91-116 